\section{Anthurium 'Show Biz'}

\section{R.J. Henny and D.J. Norman \\ University of Florida, Institute of Food and Agricultural Science, Mid-Florida Research and Education Center, 2725 Binion Road, Apopka, FL 32703}

Additional index words. Anthurium andraeanum, Anthurium amnicola, Anthurium antioquiense, Araceae, flamingo lily, floricultural production, foliage plant, plant breeding, tailflower

Anthurium andraeanum Lind. (Araceae Juss.), commonly called flamingo lily or tailflower, is produced traditionally for cut flowers due to the large showy orange, pink, red, or white spathes. Cut-flower cultivars generally develop large leaves and long petioles that diminish their use as pot plants. Newly developed interspecific hybrids, such as Anthurium 'Lady Jane' (Kamemoto and Kuehnle, 1996), Anthurium 'Southern Blush' (Henny et al., 1988), and Anthurium 'Red Hot' (Henny, 1998), are produced as flowering pot plants because they are very floriferous and possess a compact, freely branching growth habit suitable for pot production. These hybrids inherited their smaller size and branching growth habit primarily from the dwarf species A. antioquiense Engler or A. amnicola Dress. Anthurium amnicola has small lavender (RHS 75D) spathes and spadices (Royal Horticultural Society, 1995); A. antioquiense has white (RHS 156D) spathes and lavender (RHS 76A-B) spadices; $A$. 'Show Biz' is also a floriferous interspecific hybrid that produces numerous attractive light red spathes and has a compact branched growth habit. These qualities contribute to its release as a new Anthurium pot-plant cultivar(Fig. 1) from the Florida Agricultural Experiment Station.

\section{Origin}

Anthurium 'Show Biz' derived its flowering and growth habit from A. amnicola and $A$. antioquiense, both of which were involved in its pedigree (Fig. 2). These species along with an accession of $A$. andraeanum $\mathrm{G}-79$ led to development of four Mid-Florida Research and Education Center (MREC) hybrid selections, of which MREC 702 was crossed as female with Anthurium 'Lady Jane' giving rise to 'Show Biz' (Fig 2). 'Lady Jane', a popular commercial cultivar, is an interspecific hybrid that most likely has A. antioquiense in its parentage, but its exact origin is unknown (Kamemoto and Kuehnle, 1996).

Received for publication 5 Sept. 2000. Accepted for publication 3 Jan. 2001. Florida Agricultural Experiment Station Journal Series No. R- 07896. The cost of publishing this paper was defrayed in part by the payment of page charges. Under postal regulations, this paper must be hereby marked advertisement solely to indicate this fact.

\section{Description}

The description of 'Show Biz' is a typical 1-year-old plant grown in a 1.6-L pot. Leaves are lanceolate, dark green (RHS 147A), 19 to $21 \mathrm{~cm}$ long, and 11 to $12 \mathrm{~cm}$ wide near the base. Petioles are 20 to $24 \mathrm{~cm}$ long. The peduncle is yellow-green (RHS 152A-B) and extends 30 to $32 \mathrm{~cm}$ above the soil surface when the spathe is fully open. Spathes are 7 to $8 \mathrm{~cm}$ long, 3 to $4 \mathrm{~cm}$ wide, and medium red (RHS 53B) at anthesis, changing gradually to a lighter red (RHS 51B) prior to senescence. The spadix is 3 to $4 \mathrm{~cm}$ long and 5 to $6 \mathrm{~mm}$ wide. The spadix is medium purple (RHS

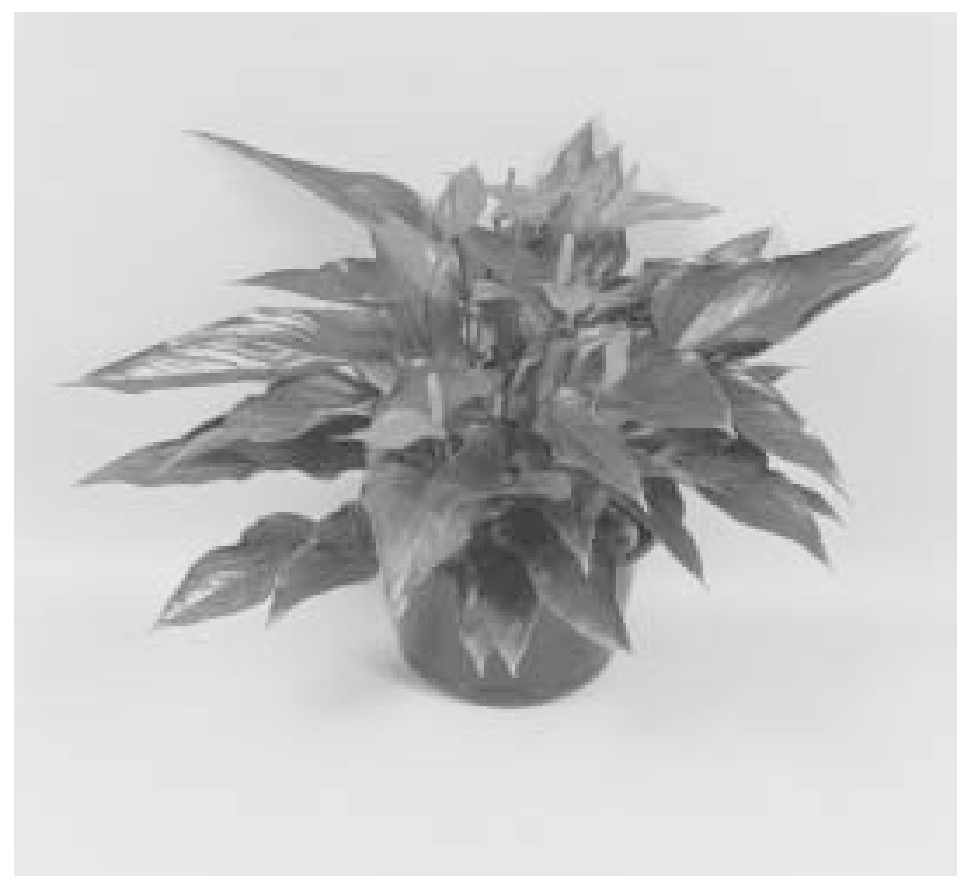

Fig. 1. A mature Anthurium 'Show Biz' in a 3.9-L pot.

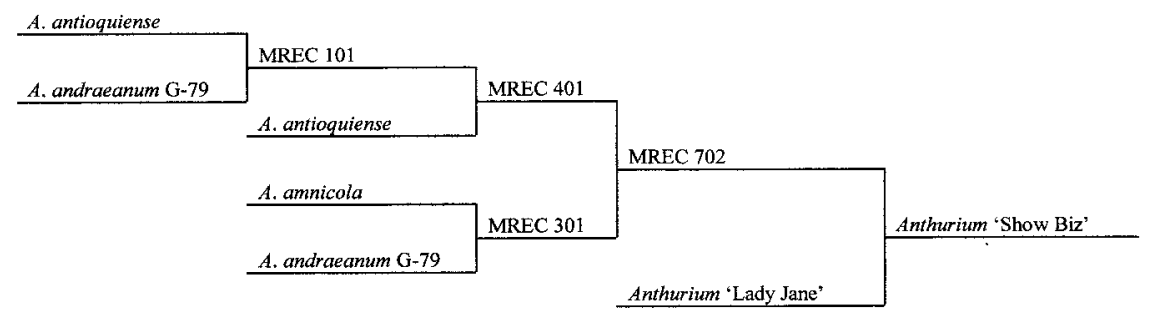

Fig. 2. Pedigree of Anthurium 'Show Biz' (female parent listed on top). 
Table 1. Size and flowering of Anthurium 'Show Biz' grown for 10 months in 1.6-L pots under 125 $\mu \mathrm{mol} \cdot \mathrm{m}^{-2} \cdot \mathrm{s}^{-1}$ maximum light intensity and natural photoperiod from November to August.

\begin{tabular}{lcccccc}
\hline \hline $\begin{array}{l}\text { Fertilizer (N) } \\
\text { applied per year } \\
\left(\mathrm{g} \cdot \mathrm{m}^{-2}\right)\end{array}$ & $\begin{array}{c}\text { Canopy } \\
\text { height } \\
(\mathrm{cm})\end{array}$ & $\begin{array}{c}\text { Canopy } \\
\text { width } \\
(\mathrm{cm})\end{array}$ & $\begin{array}{c}\text { Leaf } \\
\text { length } \\
(\mathrm{cm})\end{array}$ & $\begin{array}{c}\text { Leaf } \\
\text { width } \\
(\mathrm{cm})\end{array}$ & $\begin{array}{c}\text { Total no. } \\
\text { open } \\
\text { flowers }\end{array}$ & $\begin{array}{c}\text { Visual } \\
\text { plant } \\
\text { quality }\end{array}$ \\
\hline 59 & $29.9 \pm 3.7$ & $48.6 \pm 3.2$ & $18.9 \pm 1.1$ & $9.4 \pm 0.8$ & $9.7 \pm 2.1$ & $4.4 \pm 0.5$ \\
117 & $31.3 \pm 2.0$ & $50.9 \pm 3.0$ & $19.9 \pm 1.4$ & $9.6 \pm 0.3$ & $7.4 \pm 2.7$ & $4.9 \pm 0.3$ \\
176 & $30.3 \pm 2.0$ & $50.3 \pm 2.8$ & $19.0 \pm 1.0$ & $9.9 \pm 0.6$ & $5.1 \pm 2.5$ & $4.9 \pm 0.3$ \\
Significance & NS & NS & NS & NS & L & L \\
\hline
\end{tabular}

${ }^{2}$ Visual evaluation where 1 = poor, 2 = fair, $3=$ saleable, $4=$ good and $5=$ excellent quality.

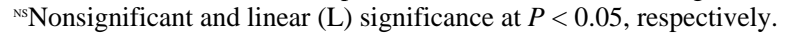

perature range of 15 to $34^{\circ} \mathrm{C}$. Ten plants were grown at each of three fertilizer levels for 10 months from Nov. to Aug. 1998 . Fertilizer levels were derived from $20 \mathrm{~N}-9 \mathrm{P}-17 \mathrm{~K}$ at $1.0,2.0$, or $3.0 \mathrm{~g} \cdot \mathrm{L}^{-1}$ applied as a liquid at 100 $\mathrm{mL}$ per pot once per week. Data taken at termination of the experiment included canopy height, canopy width, length and width of the largest leaf and visual plant quality where $1=$ poor; $3=$ acceptable and $5=$ excellent quality. Also, the number of open flowers was counted weekly during the course of the experiment. Data were analyzed using analyis of variance procedures of the SAS program (SAS Insti- tute, Cary, N.C.). Parameters with means showing significant differences were subjected to regression analysis.

Anthurium 'Show Biz' reached marketable size in 10 months. Fertilizer level did not significantly affect canopy height, canopy width or leaf size (Table 1). Flower production showed a significant linear decrease as fertilizer rate increased. Plant quality displayed a significant linear increase at higher fertilizer levels, although overall quality averaged between good and excellent at all nutritional levels. 'Show Biz' has been patented (U.S. Plant Patent No. 8820).

\section{Availability}

Patent rights were assigned to the Florida Foundation Seed Producers. 'Show Biz' is intended for commercial producers growing finished plants in 1.6- or 3.9-L containers. Plants were released to several Florida tissue culture labs for propagation and distribution. Inquiries regarding participating laboratories may be obtained by writing to the Florida Foundation Seed Producers, Inc., P.O. Box 309, Greenwood, FL 32443. Plants for research or breeding purposes may be obtained directly from the authors.

\section{Literature Cited}

Henny, R.J. 1999. 'Red Hot' Anthurium. HortScience 34:153-154.

Henny, R.J., R.T. Poole, and C.A. Conover. 1988. 'Southern Blush' Anthurium. HortScience 23:922-923.

Kamemoto, H. and A.R. Kuehnle. 1996. Breeding anthuriums in Hawaii. Univ, of Hawaii Press, Honolulu.

Royal Horticultural Society. 1995. The Royal Horticultural Society's colour chart. 3rd ed. Royal Hort. Soc., London. 